\title{
Civilisations
}

Revue internationale d'anthropologie et de sciences

humaines

58-1 | 2009

American Afrocentrism(e)s américains

\section{Africobra and the Negotiation of Visual Afrocentrisms}

\author{
Kirstin L. ELLSWORTH
}

\section{OpenEdition \\ Journals}

Édition électronique

URL : http://journals.openedition.org/civilisations/1890

DOI : 10.4000/civilisations. 1890

ISSN : 2032-0442

\section{Éditeur}

Institut de sociologie de l'Université Libre de Bruxelles

\section{Édition imprimée}

Date de publication : 31 août 2009

Pagination : 21-38

ISBN : 2-87263-026-0

ISSN : 0009-8140

Référence électronique

Kirstin L. ELLSWORTH, "Africobra and the Negotiation of Visual Afrocentrisms », Civilisations [En ligne], 58-1 | 2009, mis en ligne le 31 août 2012, consulté le 30 avril 2019. URL : http:// journals.openedition.org/civilisations/1890 ; DOI : 10.4000/civilisations.1890 


\title{
Pratiques artistiques et esthétiques afrocentristes
}

\author{
Africobra and the Negotiation of Visual Afrocentrisms
}

\author{
Kirstin L. ELLSWORTH
}

Résumé : A la fin des années 1960, Africobra, un groupe d'artistes africains-américains basé à Chicago, développa un art expérimental qui mêlait des formes africaines et africaines-américaines avec des représentations d'une diaspora africaine. Africobra mit en place un programme artistique dans le cadre duquel l'art devait faire voir la beauté d'une culture noire universelle. Leur langage visuel devance la publication de l'ouvrage "Afrocentricity " de Molefi Asante, mais évoque pourtant déjà des tendances afrocentristes présentes tout au long de l'histoire culturelle africaineaméricaine. Travaillant toujours aujourd'hui, Africobra souligne la valeur morale du processus de création pour l'artiste africain-américain travaillant dans un paradigme afrocentriste. Ce faisant, Africobra cherche à se réapproprier le pouvoir de définir ce que sont l'art et l'identité, ce qui avait été pendant des siècles aux Etats-Unis le privilège de la culture dominante.

Mots-clés : Africobra, Afrocentrisme, Etats-Unis, art africain-américain.

\begin{abstract}
In the 1960s, Africobra, a group of African-American artists in Chicago, experimented with art that synthesized African and African-American forms with interpretative visions of an African Diaspora. Africobra mandated a functional program for art-making in which art was to instruct in the beauty of a universal Black culture. Their imagery predates publication of Molefi Asante's "Afrocentricity" yet negotiates in visual terms Afrocentric tendencies present throughout African American cultural historiography. Still working in the present day, Africobra emphasizes the moral value of the creative process for the individual African American artist within an Afrocentric paradigm. In so doing, Africobra attempts recapture in an American context, the power of definition over art and identity exercised for centuries by dominant culture.
\end{abstract}

Key words: Africobra, Afrocentrism, United States of America, African-American Art. 


\section{Introduction}

$\mathrm{I}$ Afrocentricity (1988), Molefi Kete Asante posits an Afrocentric paradigm informed by engagements with the relationship of race to science, history, mythology, religion and literature. A notable omission in Asante's study is the relationship of the visual arts to the history and development of Afrocentricisms. Asante underscores the importance of symbols as catalysts for the intellectual and psychological transformations afforded by his model of Afrocentricity (Asante 1988: 2). However, he does not analyze the contributions of the field of visual arts in the creation of symbolic representations of Afrocentric themes. One may speculate the exclusion is related to a limited view of the visual arts that believes the study of art is merely subjective analysis at odds with the perceived methodologies of other disciplines. The slow growth of documentation of the field of African American art history may be another factor ${ }^{1}$. Yet the importance of the visual arts in the development of what Asante names in the 1980s as Afrocentric identity formation is indicated strongly by the American cultural revolutions of the 1960s in which, "to promote psychological wellness, activists urged that black folk embrace their own forms of cultural expression, molding them into a varied but recognizable 'style' that was "uniquely, beautifully, and personally ours"” (Van Deburg 1997: 75). In the 1960s, visual statements exploring the bond between African Americans and the African Diaspora were important elements in the construction of positive race consciousness with Afrocentric dimensions. Textiles, fabrics, and hairstyles imported from Africa and worn by African Americans, for example, expressed the claim of a shared heritage of visual forms for people of African descent dispersed across the globe. In the United States, such expressions offered African Americans one means for visualizing a transformation from denigrated American minority to self-defined participants in a thriving global Black community ${ }^{2}$. The permanency of African fashions from the 1960s and 1970s has been dictated by the vagrancies of time and marketing culture. An enduring history of visual expression that offers an early manifestation of what Kariamu Welsh identifies in the foreword to Afrocentricity as "the placement of Africa at the center of existential reality" (Welsh 1988: x) is found in the production of a group of African American artists in the same period. Organized in 1969 and working through the present day, Africobra, the African Commune of Bad Relevant Artists, has pursued a visual ideal through imagery intended to synthesize African American forms and culture with interpretative visions

1 Historically, the creation of Africana Studies departments within American universities coincided with the development of Ethnic Studies, Women's Studies and other departments dedicated to scholarly study of women and other under-represented American populations. The study of African American art within American universities has experienced a well-deserved rise in popularity in more recent years as the field of Art History seeks to revise racially exclusive narratives of the history of American art. The impetus for this article was a seminar in African American art developed in 1999 by Art Historian Dr. Janet E. Kennedy at Indiana University.

2 Throughout this article I employ terms such as "Black", "African American", "white", and "dominant culture" in the context of capturing the nuances of race discourse in American culture from the 1960s to the present. "Black", therefore, is constructed in opposition to "American Negro" and intended to communicate empowered identification with people of "African descent". The contemporary "African American" is intended to express a dual identity. The monolithic nature of the terminologies is not to be underestimated as is the case with ubiquitous "white" "dominant culture", and reflects the continued bifurcation of American society along racial lines even at the most fundamental level of nomenclature. 
of an African Diaspora. From the beginning Africobra's stated mission, as expressed in "The History, Philosophy and Aesthetics of AFRI-COBRA", "was not fantasy or art for art's sake, it was specific and functional by expressing statements about our existence as Black people" (Jones-Hogu 1973: 1). By asserting parameters for the categories of functional art and Black people, Africobra attempted to recapture in an American context the power of definition over art and identity exercised for centuries by dominant culture. Africobra's early brand of Afrocentrism proffered a dynamic interplay between the higher ideals of visualizing a universal Black identity and the creation of a community in which individuals explored what it meant to be an American artist of African descent. Africobra artist Jeff Donaldson termed the process Transafrican: "that which expresses an 'African' sensibility through the specific forms and elements found in the milieus of its artists" (Harris 1997: 34). In this context, Africobra contributes towards a prototype for the creation of visual arts within paradigms later codified as Afrocentric that provides a role for artists in the construction of the ideologies of Afrocentrism. Obviously, Asante's codification of the philosophy he terms Afrocentricism post-dates Africobra, and what I examine here is the development of Afrocentric tendencies within Africobra that precede publication of Afrocentricity and have been present throughout African American cultural historiography.

\section{The Black Arts Movement in Chicago}

The relationship of African Americans to their origins in Africa has been a contested one over the three hundred years since their forced enslavement and migration to the United States. In "Art as an Expression of Black Culture", Samuel Akainyah identifies one effect of the dispersal of people of African descent from the African continent to the United States as the growth of cities with large African American communities to serve as centers for the development of Black art (Akainyah 2003: 14). The presence of significant African American populations in Chicago, Detroit, Cleveland, Philadelphia, and other Northern industrialized cities in particular was the result of the Great Migrations between World War I and World War II when African Americans left the South to secure jobs and escape segregation. In the 1960s, an American Black Arts Movement took form in major American cities and called for new artistic expressions celebrating the beauty and contributions of African Americans after years of oppression within American society. Chicago, a city with a large African American population, was then second only to New York City as a thriving center of the Black Arts Renaissance ${ }^{3}$. In 1967, the Organization of Black American Culture (OBAC) was established in Chicago to foster the literary, theatrical, performance, and visual arts of African Americans living in the city. The OBAC was founded by Hoyt Fuller, editor of the longstanding African American periodical the Negro Digest which would become the Black World, predecessor to Ebony magazine. The OBAC was organized into a series of workshops dedicated to promoting a Black aesthetic drawn from residents of Chicago's ghetto communities which were built through decades

3 The Black Arts Movement which lasted from the mid 1960s through the 1970s brought together creative forces within the African American community on a national scale and gained momentum after the assassination of Malcolm X in 1965 when the need intensified for expressive venues for community building and addressing the shared experiences of racism. The foundation of the Black Arts Repertory Theater/ School (BARTS) in Harlem by poet LeRoi Jones (Amiri Baraka) in 1965 was a critical development in models for Black Arts institutions developed in other cities such as Detroit, Philadelphia, and Chicago. 
of discriminatory housing policies that confined the African American population to public housing projects and economically impoverished areas including the south side neighborhood known derisively as the Black Belt (Hirsch 1998: 9-10). Fuller, who mentored writers, poets, and playwrights codified many of the principles of Chicago's Black Art movement in his essay "Towards a Black Aesthetic", in which he defined the OBAC's vision of Black Art as bounded by the experience of racial segregation. Fuller asserted that the segregated environments of America's cities were more than places of loss and despair; they were repositories of latent creative production central in the redefinition of African American life. In his words, "the young writers of the black ghetto have set out in search of a black aesthetic, a system of isolating and evaluating the artistic works of black people which reflect the special character and imperatives of black experience" (Fuller 1972: 9).

The OBAC organized workshops to support new artists working in different genres including the visual. In 1967, artists in the OBAC's Visual Arts workshop initiated a public art project that culminated in a mural known as the Wall of Respect. The Wall of Respect was a series of portraits of heroes and heroines of African American history painted by OBAC artists on a brick building on $43^{\text {rd }}$ Street and Langley Avenue in the socalled Black Belt area. The corner, once a thriving economic area of the community, was dominated by gang activity, drugs, and crime. The Wall of Respect incorporated depictions of a range of African American figures including Martin Luther King, Jr., Nat Turner, Elijah Muhammad, Malcolm X, Muhammad Ali, Gwendolyn Brooks, W.E.B. Dubois, Marcus Garvey, Aretha Franklin, and Harriet Tubman. However, in 1967 increasingly polarizing interpretations of heroic action and the proper course of history emerging within the African American community caused tensions that influenced the portraits included on the Wall of Respect.

Asafa Jalata characterizes advocates of Black Power and the Black Liberation struggle as activists who sought to move, "beyond the civil rights demand" (Jalata 1995: 161) to create their own economic and cultural institutions. Black Power and Black Liberation movements associated the demands for equality within the American Civil Rights Movement with the objectives of oppressed peoples around the world. The change from what Civil Rights advocates viewed as the fight for equality-based integrationist policies within the American system to separatist politics that answered to the cause of revolution on a global scale created dissension among OBAC artists contributing to the mural. For example, some OBAC artists, community leaders and local gang members opposed the inclusion of Martin Luther King, Jr. on the Wall of Respect and demanded he be replaced by the image of Stokely Carmichael, a figure who represented the cause of Black Liberation. Before the dedication of the Wall of Respect on 27 August 1967 civil rights leaders and police confronted each other in a stand-off (Cockcroft 1973: 3-4). Internal tensions were exacerbated by evidence J. Edgar Hoover's undercover organization COINTELPRO (Counter Intelligence Propaganda) was involved in creating division among OBAC artists in order to subvert the project (Thorson 1990: 26-27).

The Wall of Respect was destroyed in a fire in 1971. Nevertheless, the mural stimulated the creation of other walls across the country committed to representing the neglected histories of minorities and other groups repressed within American society. Despite its short-lived existence, the Wall of Respect established a model for the representation of African American experiences that also introduced new means for African American self-definition with American society. The portraits rendered by women and men OBAC 
artists served as potent reminders of the faces and names of individuals largely ignored or forgotten in American history. The strategy emphasized the historical presence and continuity of minority achievement, and figures on the Wall of Respect were didactic icons intended to inspire courage and action in a neighborhood suffering from institutional, cultural, and economic racism. Even more, as a mandate for creative agency, the Wall of Respect demanded that African American artists create imagery to challenge legacies of negative depictions of African Americans such as the "darky" and the "savage" constructed for consumption by dominant audiences (Harris 2003: 76). Africobra member Nelson Stevens would later explicate the process of creating a body of new imagery to represent one's own experience as nothing less than an Afrocentric re-education of the artist: "We had all been through the same kinds of school systems that taught us the same terrible things about art. We had to unlearn art history with its lack of appreciation for African and Egyptian art, its refusal to recognize the influence of African art on European movements" (Fox 1988: 4). The pedagogical imperative described by Stevens addresses an important concept of Afrocentricity, since Asante hypothesizes there the non-Afrocentric individual as a person engaged by oppositions: "the person's images, symbols, lifestyles and manners are contradictory and thereby destructive to personal and collective growth and development" (Asante 1988: 1). However, counteracting the presence of negative images by simply replacing them with alternatives was only one part of the agenda for OBAC and other artists. From their point of view in fact, the process of art-making must bear the potential to take on transformative dimensions for the artist as well as audience.

\section{Cobra, The Commune of Bad Relevant Artists}

OBAC artists who worked on the Wall of Respect appropriated the visual language of the heroic portrait used by dominant culture to express the under-examined histories of the African American community. However, a question remained for several of the OBAC artists concerning the need for modes of representation construed as distinctly African American. Jeff Donaldson and Wadsworth Jarrell, two OBAC artists had raised the issue several years before by asking whether it was possible to start a "Negro' art movement based on a common aesthetic creed" (Douglas 1996: 26). After the collapse of the OBAC's Visual Workshop in 1967 under the political pressures associated with the Wall of Respect, Donaldson, Jarrell, and other former OBAC artists who contributed to the mural founded a collective to explore the possibility of what had become common Black aesthetic creed. Jeff Donaldson, Barbara Jones-Hogu, Wadsworth Jarrell, Jae Jarrell, Carolyn Lawrence, and Gerald Williams became Cobra, the Commune of Bad Relevant Artists. Cobra elucidated an agenda for Black visual aesthetics within a contemporary visual idiom that combined Pop Art, poster art, commercial art techniques, lettering, and fragment like patterning associated historically with African American artists including Romare Bearden, Jacob Lawrence, and John Biggers. As artists coming of age in the late 1960s, members of Cobra were engaged with the destruction of boundaries between "high and low" forms stimulated by assemblage, Pop Art, and other post World War II movements. Central to the new visual idioms was a focus on "life", or the new technologies, architectures, and objects of a postwar American bent on advertising its economics of planned obsolescence and constant consumption. As they cultivated the contemporary visual strategies, Cobra isolated themes of self-determination and universal 
Black liberation furthered by Malcolm X, the Black Panthers and other African American activists as the appropriate subjects for a new art.

Thirty years after the foundation of Cobra, Donaldson recalls a pivotal moment in the group's understanding that Cobra would not fit into established arts institutions as a 1968 conference at Columbia College in Chicago dedicated to raising the profile of African Americans in the arts. He and other soon to be members of Cobra realized they would have to create their own venue for action when it became clear, in his words, that "we who had struggled in the trenches in Chicago since time immemorial were totally overlooked when they selected the so-called experts to talk about developing something" (Thorson 1990: 27). At the same time, the failure of the American system to accommodate dissent on a national level was epitomized by the violent events of the 1968 Chicago Democratic Convention during which the brutalization by police of African American and other demonstrators was televised across the nation ${ }^{4}$. On August 28, 1968, over ninety million Americans watched footage of demonstrators outside the convention hall beaten by police, images that would be televised repeatedly (Culbert 1998: 438). For many, the footage reinforced the extent to which the nation had succumbed to violence at home and abroad in Vietnam. The police response at the convention also confirmed routine mistreatment of African Americans and other American minorities by police. After the convention, Cobra chose to express their response to the realities of American racism with a series of paintings dedicated to the subject of the Black Family. In 1965, Daniel Patrick Moynihan, one of Lyndon Johnson's theoreticians of the War on Poverty had asserted that, "black culture was a product of a 'social pathology' whose source was the unstable black family" (Miller 1987: 177)5. Moynihan's Report reinforced a national legacy of racist images of African American life. Cobra's aesthetic requirements for their Black Family series called for the visualization of the dignity of African Americans informed by the traditions of the OBAC and the portraiture on the Wall of Respect. Each member of Cobra contributed an image that addressed the group theme and followed prescriptions recorded later by Africobra artist Barbara J. Jones-Hogu in "The History, Philosophy and Aesthetics of AFRI-COBRA":
The visual statement must be humanistic with the figure frontal and direct to stress strength ... the subject matter must be completely understood to the viewer, therefore requiring lettering to clarify the visual statement...the visual statement must identify our problems and offer a solution, a pattern of behavior, or attitude...the visual statement must educate, it must speak of our past, present, or future...[and make] Black, positive, direct statements created in bright, vivid, singing cool-ade colors of orange, strawberry, cherry, lemon, lime, grape (Jones-Hogu 1973: 2).

Cobra's "Black, positive, direct statements...in bright, vivid singing cool-air colors" employed popular commercial art colors and lettering in the service of articulating an emerging Afrocentric conception of African Americans as Black people striving to reenvision their world apart from the restraints of their position as American minorities. Cobra's principles also resonated with emerging models for Black Cultural Nationalism

4 I would like to thank Paul Cronin, Ph.D. student in English at Columbia University for suggesting to me the importance of the 1968 Chicago Democratic Convention in the birth of Cobra.

5 Johnson announced a War on Poverty in his inaugural address of 1964, a declaration that culminated in the Economic Opportunity Act of the same year. 
in which African American identity was aligned with an Africa Diaspora. E. Frances White criticizes Black Nationalist leaders of the 1960s and 1970s for putting forth an "ideology of respectability to develop a cohesive political movement" (White 1990: 76). One critique implicit within the assertion of respectability is the notion that in America, the audiences for imagery such as that presented in Cobra's Black Family series, were understood as white. Cobra artist Wadsworth Jarrell voiced a different view in which the group enterprise of Cobra gave the African American artist a system for self-definition beyond the boundaries of nation and time:

These seemingly confining methods of making art had room for improvisations because we believed that the spiritual being of the COBRA artists could transcend unjust and oppressive measures in their lives, and spur them on to enhance their artistic potentialities by expressing them in bold brilliant colors, and powerful engaging images (Jarrell 1985: 17).

Jarrell's statement expresses Cobra's belief in the ability of the individual to move beyond the circumstances of racism through creative processes. By aligning visual expression to humanistic philosophies integral to American identity, Cobra demanded equal access to the means for a psychological sense of liberation denied them by the dehumanizing histories of racism. Like the American heroic portrait, also borrowed from dominant culture, for Cobra, visual expression was cast in terms of the heightened individuality of American egalitarianism. In this context, respectability was understood as a process of self-understanding also evidenced in Cobra's a second group series titled "I am Better Than Those Mother Fuckers". In the series, artists highlighted letters representing the phrase "Mother Fucker" such as "mf" or "bad mf" in posters and paintings of subjects ranging from famous African American musicians to ordinary African American people. The use of colloquial slang actualized Cobra's identity as "bad" anti-establishment artists working against the constraints of dominant culture now defined by a derogatory term in the same fashion African Americans had been labeled historically in deprecating terms. However, the language also promoted what Van Deburg poses as a "revitalized sense of self" (Van Deburg 1987: 74) or an aggressive self-respectability intended to invert dehumanizing and delimiting narratives of African American identity.

\section{The Emergence of Africobra}

Cobra's embrace of an emerging Afrocentric ideology led the group to change its name to Africobra, the African Commune of Bad Relevant Artists, in 1969. Africobra was comprised of the original Cobra members with the addition of Napoleon Henderson and Nelson Stevens ${ }^{6}$. In 1969, Africobra artists turned more overtly toward the vast Diaspora of people of African descent as a context and environment for their work. The "Africa" constructed by the newly minted Africobra was the product of intensive study of the art of specific African cultures, as well as continued emphasis upon the relationship of African Americans to the concerns of a broadly conceived Black global community. Africobra's construction of the African Diaspora was geographical, philosophical and Utopian at the same time. In "Unfinished Migrations: Reflections on the African Diaspora and the Making of the Modern World”, Tiffany Ruby Patterson and Robin D.G. Kelley conclude,

6 Membership in Africobra has grown over the years to include artists Adger Cowans, Akili Ron Anderson, James Phillips, Michael Harris, Frank Smith, and Murray DePillars (deceased). 
"the linkages that tie the Diaspora together must be articulated and are not inevitable... the Diaspora is both process and condition" (Patterson and Kelley 2000: 11). To the extent that Africobra created imagery to serve an African Diaspora, their Afrocentrisms were defined by their identities as African Americans and artists. The "process and condition" of existing within the Diaspora became a personal and artistic source from which to draw and circumscribe experience. The imagery of Africobra was therefore posed as transformative for the creators in ways that synthesized the personal and the political in the same manner Cobra had asserted, "the visual statement must identify our problems and offer a solution, a pattern of behavior, or attitude" (Jones-Hogu 1973: 2).

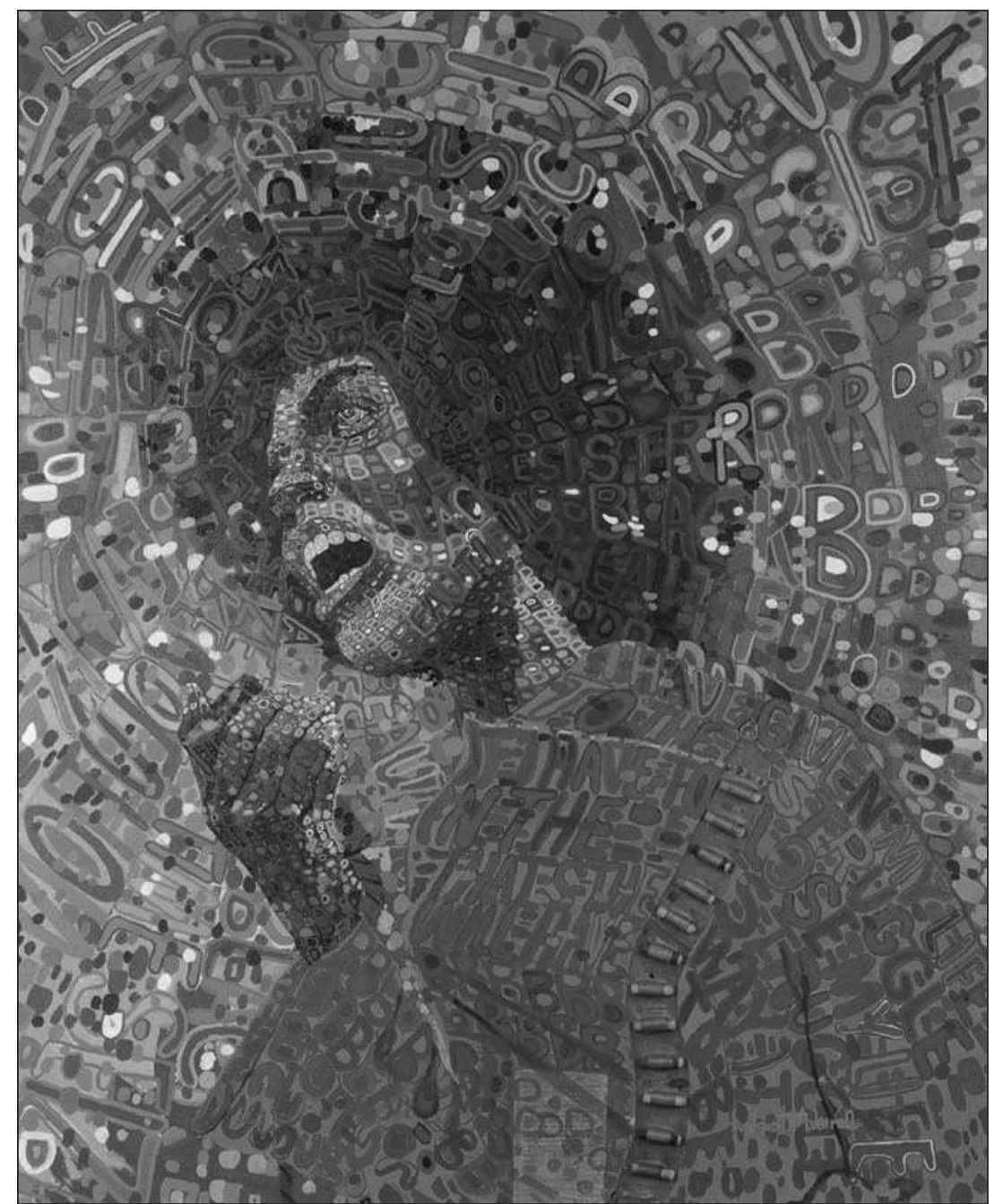

Figure 1

Wadsworth Jarrell, Revolutionary, 1971. Acrylic on canvas, $631.2 \times 50$ 1/2”.

(C) Permission of the artist. 
Wadsworth Jarrell's portrait of Angela Davis titled Revolutionary (1971) (figure 1) was part of a series of depictions of individuals who positioned the struggles of African Americas as part of a larger agenda for self-determination for people of African descent living under postcolonial systems. Malcolm X, one of the subjects in Jarrell's series, asserted that, "All Black people, regardless of their land base have the same problems, the control of their land and economics by Europeans or Euro-Americans" (cited in Douglas 1996: 19). Angela Davis, a member of the Black Panthers, called for women to join in the struggle for Black self-determination in America. Jarrell follows the aesthetic criteria put forth by Cobra and adopted by Africobra in Davis's portrait. Davis's body is composed of the text of her famous statement, "I have given my life to the struggle" and her figure is in semi-profile to express strength. The repetition of the letter B reiterates the words "Blackness" and "Beauty". She is presented in the very act of taking the message to the people: offering a solution to the problem of racial oppression. Bright "cool-ade" colors named for the powdered drink render Davis's portrait within contemporary visual paradigms derived from commercial aesthetics. The real cartridge belt attached to the canvas is a challenge to the conventions of painting as solely two dimensional revolutionized in American art of the 1960s and 1970s; the belt also underscores the potential for violence from all sides in the process of changing radically the situation of oppressed peoples.

\section{Afrocentric Aesthetics}

In effect, Africobra's inscription of Angela Davis as an icon of pride and revolutionary change differs quite radically from rhetoric concerning the role of the Black woman as "baby maker" put forth during the period by activists such as Ron Karenga ${ }^{7}$ and echoed in Asante's discussion of woman as identified primarily with creation (Asante 1988: 53). Additionally, Africobra's treatment of Davis was not limited to painted representation and extended to the world of popular fashion. In 1970, Jae Jarrell, Africobra textile artist, designed a two piece revolutionary suit for Angela Davis featuring a belt-and-bullet trim. Jarrell's design appropriated the Fifth Avenue couture design of the Coco Chanel suit in the service of querying systems of economic and racial exclusion. The use of different media within Africobra also affirmed the personal interests of the individual artists within the group; to this day Africobra artists maintain independent careers as practitioners, teachers, and scholars. In its early period, Africobra sought diversity of form through the creation of affordable silk-screen prints of paintings and other objects for the public (Douglas 1996: 34). Africobra also altered Cobra's aesthetics to incorporate forms associated with arts from Africa, visual culture Africobra viewed as the inheritable art forms of all African people (Jones-Hogu 1973: 2). By 1973, Africobra's refined aesthetic manifesto included five formal qualities:

FREE SYMMETRY, the use of syncopated rhythmic repetition which constantly changes in texture, shape, form.... MIMESIS at MID-POINT, design which marks the spot where the real and the unreal, the objective and the non-objective, the plus and the minus meet... a point exactly between absolute abstraction and absolute naturalism.... VISIBILITY, clarity of form and line based on the interesting irregularity one senses in a freely drawn circle or organic object... LUMINOSITY,

7 Karenga is discussed in the section of this article related to Africobra/Farafindugu. 
'Shine', literal and figural, as seen in the dress and personal grooming of shoes, hair (process or Afro), laminated furniture, faces, knees, or skin.... COLOR, Coolade color, bright colors with sensibility and harmony (Jones-Hogu 1973: 2).

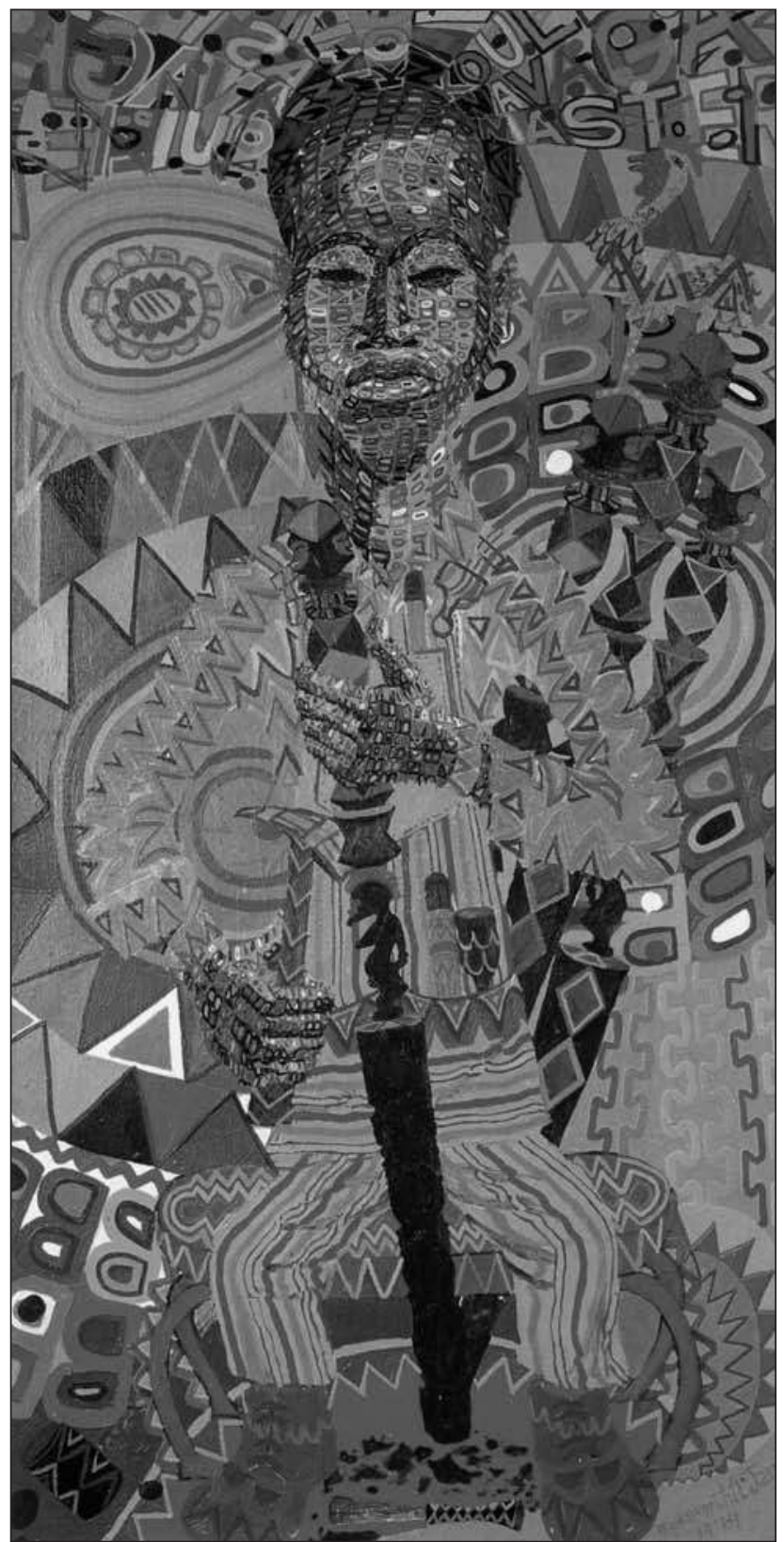

Figure 2

Wadsworth Jarrell, Navaga, 1974. Acrylic on canvas, 24 x 50". (C) Permission of the artist. 
In fact, Africobra's aesthetic statement bears a striking resemblance to Robert Farris Thompson's pivotal study of West African Yoruba aesthetics also published in 1973. In his article, Thompson articulates qualitative criteria of Yoruba visual arts, among them: "'midpoint mimesis', between absolute abstraction and absolute likeness"; "visibility... clarity of form and clarity of line"; and "shining smoothness" (Thompson 1973:31-34; 37). To date the similarities between Africobra's and Thompson's descriptive language have been neither noted nor commented upon. However, Africobra's relationship to the study of African art was integral to their work from the beginning and Africobra artists, many of whom pursued degrees in African art and traveled to Africa, remain important scholars of African and African American art today. In the late 1960s and the 1970s, many African Americans returned to Africa as nations gained independence after decades of colonial rule. The scholarly examination of art from Africa also gained stature during the period within American universities, many of whom founded Africana Studies departments at the same time. Moyo Okediji posits a new category of African American artist from the period, the "returnee artist", who returned to Africa, and "personally experienced the warmth and the cold, sniffed the earth, and felt the textures of the old continent" (Okediji 1999: 51).

Many Africobra artists became returnee artists. As a graduate student at Howard University, Wadsworth Jarrell studied the art of the Senufo of the modern nations of Côte d'Ivoire, Mali, and Burkino Faso; in the late 1970s he traveled to West Africa. Navaga (1974) (figure 2) is a portrait of the navaga or traditional Senufo woodcarver that synthesizes Senufo form with Africobra's aesthetics. Jarrell's navaga may reflect in particular the specific forms of the Kulebele carvers who are an ethnic artisan group associated with the Senufo whose sculptures are still produced and sold by family-operated workshops in the northern Côte d'Ivoire (Steiner 1994: 80). Jarrell's navaga is rendered with Africobra's signature syncopated, high-intensity "cool-ade" color. The expression on the navaga's face expresses a dignified sense of inner focus or contentment suggested of "luminosity" or "shine". Free symmetry of repetition dominates the background and the familiar yet abstracted Baule navaga demonstrates mimesis at midpoint. Jarrell's decision to compose the navaga's face by abstracting a photograph of his own father's face in Senufo style (Douglas 1996: 44) integrates African American family history with the larger global history of African people. In Navaga, Jarrell also visualizes a lineage for Afrocentric artistic identity and production in which the contemporary African American artist continues the work of the traditional artisan from Africa, a connection Africobra explored further in FESTAC '77, The Second World Black and African Festival of Arts and Culture.

\section{FESTAC ' 77}

The different narratives communicated by Navaga exemplify the degree to which Africobra's negotiation of Afrocentricity stimulated the creation of multi-layered forms for self and community definition. The imagery and ideas contributed to a sense of creative agency understood by Africobra in transformative terms: "Black artists are immigrating into self, family, nationhood, and celebrating the process" (Jeffries 1974: iv). Africobra's visual Afrocentrisms were not limited to the work of artists who went to Africa. Africobra also directed its imagery toward African Americans at home and gained an audience through exhibition in primarily African American-based arts institutions. The group exhibited in local Chicago venues including the Af-Am (African American) Gallery and the Southside 
Community Art Center. In 1970, Africobra had its first exhibition at the Studio Museum in Harlem and throughout the 1970s participated in traveling exhibitions at historically African American colleges and universities. In 1977, Africobra was invited to participate in FESTAC '77, The Second World Black and African Festival of Arts and Culture held in Lagos, Nigeria (The First World Festival of Negro Arts was held in Senegal ten years earlier). Over 15,000 artists from countries around the world participated in the festival which took place from 15 January-12 February, 1977. People of African descent from across Africa and the globe were invited to FESTAC ' 77 and organized by geographical zones. Jeff Donaldson led the delegation of artists from the North American zone, and Jae Jarrell chaired the FESTAC Committee of Creative Modern Black and African Dress (Douglas 1996: 101-102). Events included art exhibitions, dance performances, musical performances, colloquia, and workshops. Africobra artists exhibited their work in the National Theater Gallery in Lagos and pursued side trips to other parts of West Africa.

The official stated mission of FESTAC ' 77 was to present "Black and African culture in its highest and widest conception", and in the same FESTAC ' 77 program, Nigerian artist Ben Ewonwue expressed the relationship FESTAC ' 77 desired to forge with people of African descent no longer living on the continent:
Black people abroad (who have assumed whatever culture they now live in) will be able to exchange culture and appreciate their black brothers' cultural life. In the U.S. of America or Cuba where the original African culture has been transformed though slavery, FESTAC would rekindle the cultural affiliation Blacks in such places have with their brothers in Africa. In fact, the sort of culture they'll take back with them can be described as a neo-Blackism (FESTAC' 77 Souvenir 1977: 36).

Ewonwue's declaration gave new status to concepts of Afrocentricity in the work of Africobra. In certain respects, FESTAC ' 77 was an expansion of earlier ideas of PanAfricanism now applied beyond the geographical and imagined borders of the African continent. FESTAC ' 77 not only acknowledged Africa as the source of an originating culture still present (even if transformed) within African American society, the festival reiterated the relationship through the visual arts. FESTAC '77's separation of Black and African "culture" allowed African American artists to recover a Black identity from the double bind of their position as minorities within American society and exiles from an African homeland. However, FESTAC '77's negotiation of culture was not without limitations. The "African culture" displayed in FESTAC '77's performances and exhibits was selective; groups were invited to represent regions and display forms associated predominantly with "traditional" arts from Africa. The model furthered understandings of art from Africa as static and unchanging with an emphasis upon reconstructing a pre-colonial Africa unaffected by outside influences. FESTAC '77's neo-Blackism also presumed a one-way linear course of influence from FESTAC to Black people of the African Diaspora. Africobra's subjects from African American culture rendered in terms identified with African aesthetics challenged the assumption that artists from the Diaspora could not offer viable revisions of African forms. Yet despite the inclusion of groups like Africobra, FESTAC ' 77 was concerned on the whole with providing a forum for people of the African Diaspora to retrieve the forms and ideas of a continent previously construed as lost to them by virtue of forced migration.

As a staged performance lasting for only one month, FESTAC ' 77 was by definition artificial and restricted in terms of its ability to fulfill an ambitious if not impossible role 
as a "World Black and African Festival of Arts". From a contemporary point of view, FESTAC '77's assumptions concerning African and Black art and culture were barriers to more complex understandings of the African Diaspora furthered by postcolonial ideologies. Andrew Apter describes FESTAC ' 77 as a manifestation of, "a process that converts cultural objects and materials into icons of a 'higher' symbolic order - a sanctified regime of national value and spectacle" (Apter 2007: 7). The process of nationalism described by Apter and upheld by FESTAC ' 77 is similar to the limitations of paradigms for Afrocentricity that look solely to an "African" past for a usable Afrocentric present without acknowledging the constructed nature of either. Apart from the ideological inconsistencies, FESTAC '77's emotional impact on participants was a less quantifiable and enduring by-product of the event. As one FESTAC ' 77 observer explained:

An important feature of the festival was the colloquium, consisting of a series of lectures and workshops. These filled a good part of each day and were a forum for the more academically inclined while providing an outlet for considerable pent-up emotion. The themes were familiar - the lack of intellectual freedom and ambivalence experienced by Third World countries that must turn to their old masters for expertise while attempting to establish an image of confidence and independence to themselves as well as the rest of the world (Kay 1977: 51).

"Familiar themes" of the need for identity separate from the confines of oppressive colonial or dominant cultures brought to the forefront at FESTAC ' 77 resonated with Africobra's quest for visual expressions to convey the confidence of African American artists working within a larger community of Afrocentric people. Transafricanism, Jeff Donaldson's term for the relationship of ideas stimulated by FESTAC ' 77 and Africobra's engagement with Africa, promoted a means for synthesizing the emotional, historical, and philosophical experiences of artistic identity forged in an African Diaspora. Transafricanism, or "that which expresses an 'African' sensibility through the specific forms and elements found in the milieus of its artists" (Harris 1997: 34) also allowed Africobra the freedom to embrace many Afrocentrisms rather than one vision of Afrocentricity. Moreover, Africobra's Transafrican aesthetics were determined by individual artists who synthesized their process and identity within those parts of Afrocentric culture that had the most meaning. After his condemnation of what he perceived as FESTAC '77's construction of a reductive form of African cultural production, Wole Soyinka explained: "Culture is not parts. It is not even a sum of parts, but a summation, a synthesis. That is why culture sometimes leaves one dissatisfied in its definitions" (Soyinka 1990: 110). Visual, personal, and cultural selectivity were integral and acceptable in Africobra's Transafricanism; Transafricanism relieved the artist from the burden of defining in singular terms and therefore delimiting fashion the promise of Afrocentricity as a context for expression.

\section{Africobra/Farafindugu}

After FESTAC '77, Africobra changed its name to Africobra/Farafindugu. Africobra/ Farafindugu artist Frank Smith posited the meaning of the Malinke word Farafindugu as, "the complex concept of blackness, brother-hood and black land" (Africobra/ Farafindugu 1979). Africobra/Farafindugu's invocation of a brotherhood of artists mirrors Ewonwue's language in the FESTAC ' 77 program. The patriarchal language of Black Cultural Nationalism was pervasive throughout the history of the movement. In 1972, 
Ron Karenga's manifesto typified the patriarchal view of many activists (Karenga 1972). Karenga called for a new generation of men to resist oppression by asserting patriarchal authority deemed lacking in their fathers: "We will not submit to the resignation of our fathers who lost their money, their women, and their lives and sat around wondering 'what did they do to be so black and blue" (Karenga 1972: 38). Constructions of masculine power and feminine passivity were also a difficult binary to cross in Karenga's and others' constructions of gender roles within Black Cultural Nationalism. In its different manifestations as Cobra, Africobra, and Africobra/Farafindugu, Africobra was always comprised of women and men artists. Barbara J. Jones-Hogu, Carolyn Lawrence, Jae Jarrell, and Africobra/Farafindugu affiliate artist Michelle Talibah Fennell participated in the writing of the groups' manifestoes as well as artistic creation. While it is a challenge to reconcile Africobra's and Africobra/Farafindugu's use of the term brotherhood with expectations for gender inclusive language to reflect the presence of women artists in the group, it might be argued that at the time, the Women's Right Movement was in its early phase and identified most often with the concerns of women from the dominant (white) culture. The accompanying term "sisterhood" was also used by Africobra to refer to women by women and men artists alike ${ }^{8}$. Notwithstanding the gendered semantics of the concept of brotherhood, Africobra/Farafindugu's use of Farafindugu to connote "blackness, brother-hood and black land" in a new group theme focused upon the subject of Soweto was conceived to be inclusive of all people of the African Diaspora.

After the experience of contact with the larger community of people of African descent at FESTAC '77, artists in Africobra/Farafindugu, many of them returnee artists in Okediji's sense of the term, dedicated themselves to a group series on the struggles of African people living under apartheid in South Africa. Apartheid for Africobra/Farafindugu represented a universal oppression of people of African descent associated with the enslavement of African Americans. On June 16, 1976, Soweto, a segregated African district in South Africa, was the scene of a brutal massacre of more than five hundred African students by South African police. The students were protesting the government's mandate that classes be taught in the Afrikaans language rather than in English. In his drawing Soweto (1979) (figure 3), Nelson Stevens chose to depict an act of humanity in the face of the terror and tragedy of the massacre. Two students carry an injured, or killed, classmate while they all stand in the line of fire. Despite the onslaught, the figures remain active and strong, unified in their collaborative effort to resist injustice. Steven's drawing epitomizes Africobra/ Farafindugu's visual imperative for positive resistance to actions intended to dehumanize Black people. The image synthesized Africobra/Farafindugu artists' understanding of their history of oppression with the experiences of another community of people of African descent. The Soweto series gave visual expression to a tangible expression of a shared "we" but with the intent to take positive actions to act in unity to correct the situation. The mandate was recorded in Africobra's earliest manifesto in language from which the group never deviated: "We were aware of the negative experiences in our present and past but we wanted to accentuate the positive mode of thought and action" (Jones-Hogu 1973: 2).

8 When reduced to the common term "brotherhood" the language does appear restrictive especially for contemporary audiences nonetheless. 


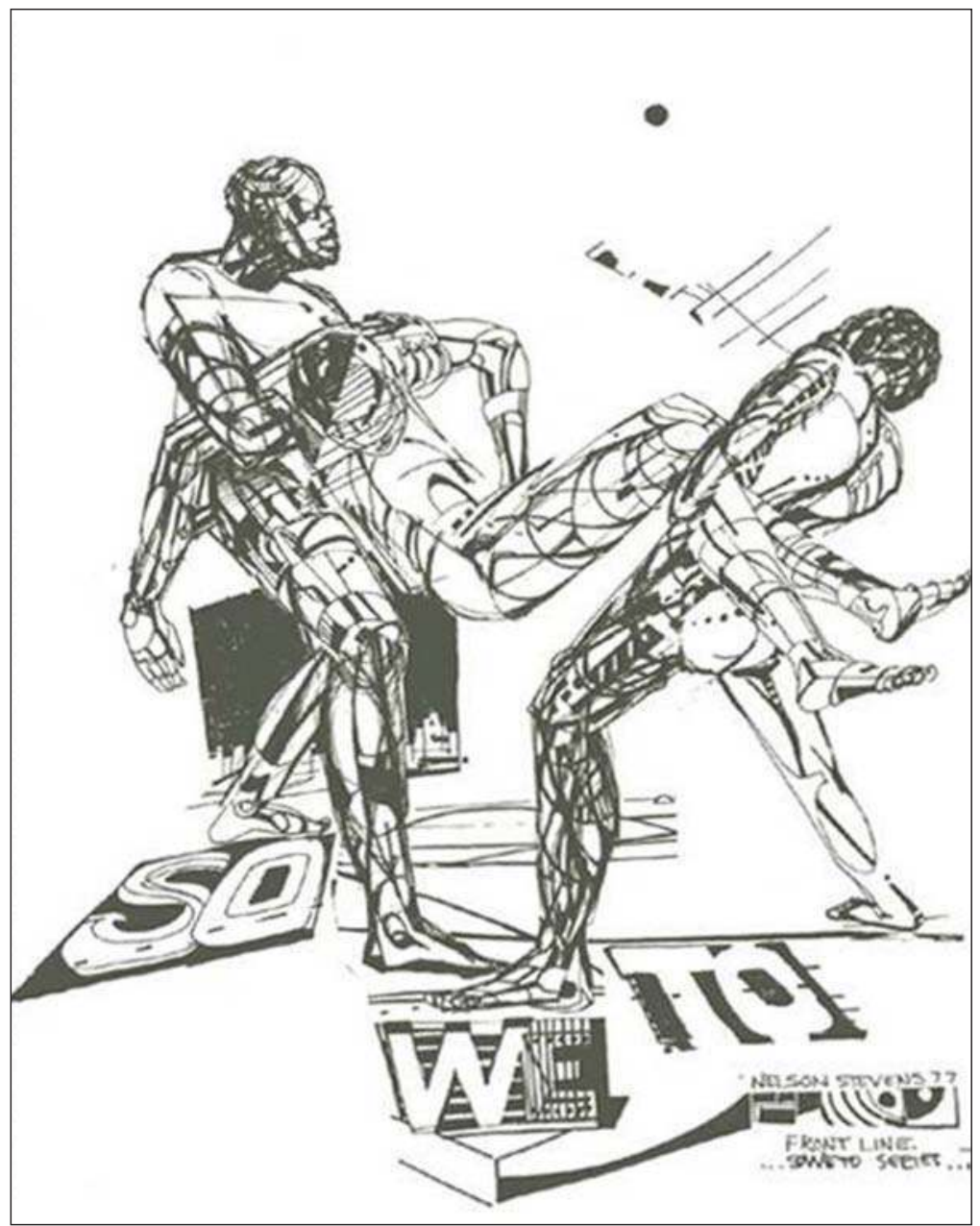

Figure 3

Nelson Stevens, Front Line, from the Soweto Series, 1977.

(C) Permission of the artist. 


\section{Conclusions}

As the 1980s approached, Africobra remained a vital and productive group with members dispersed across the United States ${ }^{9}$. Africobra artists such as painter James Phillips pursued more abstract compositions incorporating imagery from Africa, specifically figures from West African Dogon arts and myth and Central African, Kongo Kingdom, and Kuba textile design and body art. In 1991, the Nexus Contemporary Art Center and Black Arts Festival in Atlanta, Georgia organized a touring exhibition titled Africobra: The First Twenty Years that included recent work by Africobra artists with titles such as Stop Genocide (Napoleon Jones-Henderson), Homage to Issac Murphy (Wadsworth Jarrell), and Masque de Dracoulaba D'Haiti (Frank Smith). Africobra continues to render subject matter derived from African American experiences and those of people of African descent across the African Diaspora. Although Africobra does not work in terms of group images to the extent they did in the 1970s, artists continue to create visual statements within the aesthetic paradigms developed over the past forty years making them one of America's longest working art groups. In the twenty-first century, Africobra artist Akili Ron Anderson has extended Africobra's Afrocentric visual arts to the realm of public art. In 2002, Anderson created a glass panel installation for the Washington, D.C. metro-line depicting an abstraction of the Sankofa bird of traditional West African Asante art. The Sankofa bird is associated with the importance or returning to one's roots to move forward, a useful metaphor for Africobra which has always looked to the future while mindful of the legacies, both positive and negative, of the past.

Africobra is a manifestation of Afrocentrism defined by complex creation, idealism, ideological tolerance, and technical virtuosity in the visual arts. The history and expressions of Africobra afford an incomparable willingness to provide imagery for revolution and change within the confines of optimism. Ron Karenga once charged: "in terms of painting, we do not need pictures of oranges in a bowl or trees standing innocently in the midst of a wasteland. If we must paint oranges and trees, let our guerrillas be eating those oranges for strength and using those trees for cover" (Karenga 1972: 34). If African American artists associated with the cultural revolutions of the 1960s had followed the prescription, visual artifacts of the Black Arts Movement and its Afrocentric-oriented offspring would remain few and far between. For Africobra, the symbolisms of Afrocentrism are not generated by a narrow survey of art from Africa or a limited inventory of approved subjects for the revolution. Afrocentrism was a process and a product whose fullest potential was realized through the act of committing experience to image. The persuasiveness of their imagery is evidenced by their endurance in the present day, a condition presaged in the title of a group exhibition in the late 1970s, namely Africobra/Farafindugu: Celebrations and Survivals.

9 Farafindugu has been dropped from Africobra's name in present day usage. 


\section{Africobra and the Negotiation of Visual Afrocentrisms}

\section{References cited}

Africobra/Farafindugu, 1979. Exhibition Brochure, publisher unknown.

Akainyah, Samuel, 2003. "Art as an Expression of Black Culture" in The Art of Culture: Evolution of Visual Arts by African American Artists in the Last Fifty Years, pp. 14-17. Chicago: Africa International House.

Apter, Andrew, 2007. The Pan African Nation: Oil and the Spectacle of Culture in Nigeria. Chicago: University of Chicago Press.

Asante, Molefi Kete, 1988. Afrocentricity. Trenton: Africa World Press.

Cockcroft, Eva, 1973. Towards a People's Art: The Contemporary Mural Movement. New York: Holt, Rinehart, and Winston.

Culbert, David, 1998. “Television's Visual Impact on Decision-Making in the USA, 1968: The Tet Offensive and Chicago's Democratic Convention”, Journal of Contemporary History, 33 (3), pp. 419-449.

Douglas, Robert L, 1996. Wadsworth Jarrell: The Artist as Revolutionary. San Francisco: Pomegranate Art Books.

Festac '77, Souvenir, 1994. Lagos: Pioneer Publications.

Fox, Catherine, 1988. “Twenty Years Later, Africobra's Colors Still Vibrant”, The Atlanta Journal \& Atlanta Constitution, 4-5, 17 January.

Fuller, Hoyt, W., 1972. "Towards a Black Aesthetic”, in Addison Gayle, Jr. (ed.), The Black Aesthetic, pp. 3-12. New York: Doubleday/Anchor.

HARris, Michael D.,

1997. “Confluences: Ile-Ife, Washington, D.C., and the Transafrican Artist”, African Arts, 30 (2), pp. 34-94.

2003. Colored Pictures: Race and Visual Representation. Chapel Hill: University of North Carolina Press.

Hirsch, Arnold R., 1998. Making the Second Ghetto: Race and Housing in Chicago, 1940-1960. Chicago: University of Chicago Press.

JalatA, Asafa, 1995. “African American Nationalism, Development, and Afrocentricity: Implications for the Twenty-First Century" in Dhyana Ziegler (ed.), Molefi Kete Asante and Afrocentricity: In Praise and in Criticism, pp. 153-174. Nashville: James C. Winston.

JARrell, Wadsworth, 1985. "Heading for a Black Aesthetic", Art Papers, 9 (6), pp. 16-19.

Jeffries, Rosalind, R., 1974. "Introduction" in Directions in African American Art, pp. i-iv. New York: Herbert F. Johnson Museum of Art, Cornell University.

Jones-Hogu, Barbara, 1973. "The History, Philosophy and Aesthetics of AFRI-COBRA" in AFRI-COBRA III, pp. 1-5. Amherst: University Art Gallery.

Karenga, Ron, 1972. "Black Cultural Nationalism”, in Addison Gayle, Jr. (ed.), The Black Aesthetic, pp. 32-38. New York: Doubleday/Anchor.

KAY, Iris, 1977. "FESTAC 1977”, African Arts, 11 (1), pp. 50-51.

Miller, Douglas T., 1987. Visions of America: Second World War to the Present. St Paul: West Publishing.

Okedis, Moyo, 1999. "Returnee Reflections: Transatlantic Transformations”, in Michael D. Harris, Transatlantic Dialogue: Contemporary Art In and Out of Africa, pp. 47-63. Chapel Hill: University of North Carolina Press.

Patterson, Tiffany Ruby and D.G. Kelley, 2000. "Unfinished Migrations: Reflections on the African Diaspora and the Making of the Modern World", African Studies Review, 43 (1), pp. 11-45.

SoyinkA, Wole, 1990. “Twice Bitten: The Fate of Africa’s Culture Producers”, PMLA, 105 (1), pp. 110-120. 


\section{Kirstin L. ELLSWORTH}

SteIner, Christopher, 1994. African Art in Transit. Cambridge: Cambridge University Press.

Thомpson, Robert Farris, 1973. "Yoruba Artistic Criticism", in Warren L. Azevedo (ed.), The Traditional Artist in African Societies, pp. 19-61.

THorson, Alice, 1990. “Africobra-Then and Now”, New Art Examiner, 17, pp. 26-31.

Van DebuRg, William, L., 1997. Black Camelot: African American Culture Heroes in Their Times, 1960-1980. Chicago: University of Chicago Press.

Welsh, Kariamu, 1998. "Foreword", in Molefi Asante, Afrocentricity. Trenton: Africa World Press.

Whiтe, E. Frances, 1990. “Africa on My Mind: Gender, Counter Discourse, and African American Nationalism”, Journal of Women's History, 2 (1), pp. 73-95. 